\title{
Ablepharon macrostomia syndrome
}

\author{
N J Price, R E Pugh, P A Farndon, H E Willshaw
}

\begin{abstract}
The association of congenital ablepharon with the absence of eyelashes and eyebrows, a wide mouth (macrostomia), and auricular, nasal, genital, and other systemic anomalies has been termed the ablepharon macrostomia syndrome. One such case is reported which illustrates the importance of immediate postnatal ocular management to minimise severe visual loss.
\end{abstract}

Various rare congenital anomalies of the eyelids are known to be associated with other developmental defects. In the ablepharon macrostomia syndrome (AMS) complete absence of all eyelids, a large mouth, absence of eyebrows and eyelashes, low set abnormal pinnae, irregular anterior nares, flattened malar eminences, dry, coarse and redundant skin, absence of lanugo, webbed fingers, absent or vestigial nipples, ambiguous genitalia, cryptorchidism, and ventral hernia may be found.

We believe only three cases of AMS have been reported, the first two by McCarthy and West ${ }^{1}$ and a third by Hornblass and Reifler. ${ }^{2}$ We report a further case highlighting the need for urgent eyelid construction.

\section{Case report}

The baby was born in July 1986 to a primigravid mother aged 28 years and non-consanguinous father aged 35 years. There was no family history of congenital abnormalities. Pregnancy had been uncomplicated. The following congenital abnormalities were noted at birth; shallow orbits with inadequate eyelids (Fig 1), hypertelorism, large square mouth (Fig 2), protrusion of maxilla, and malformed and low set ears. The skin was wrinkled and hairless; lashes and eyebrows were absent. The genitalia were ambiguous.

Haematological, biochemical, and hormonal profiles and CT scan of the head were all reported as normal. Chromosomal analysis revealed a normal male karyotype.

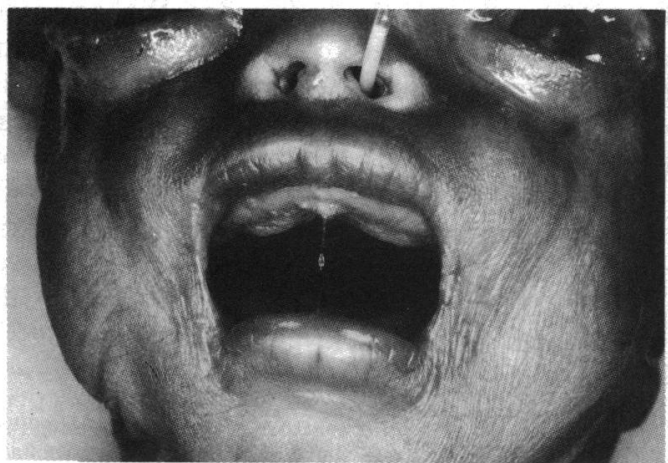

Figure 2 Macrostomia, large square mouth with apparent failure of fusion of the lateral lip clefts.

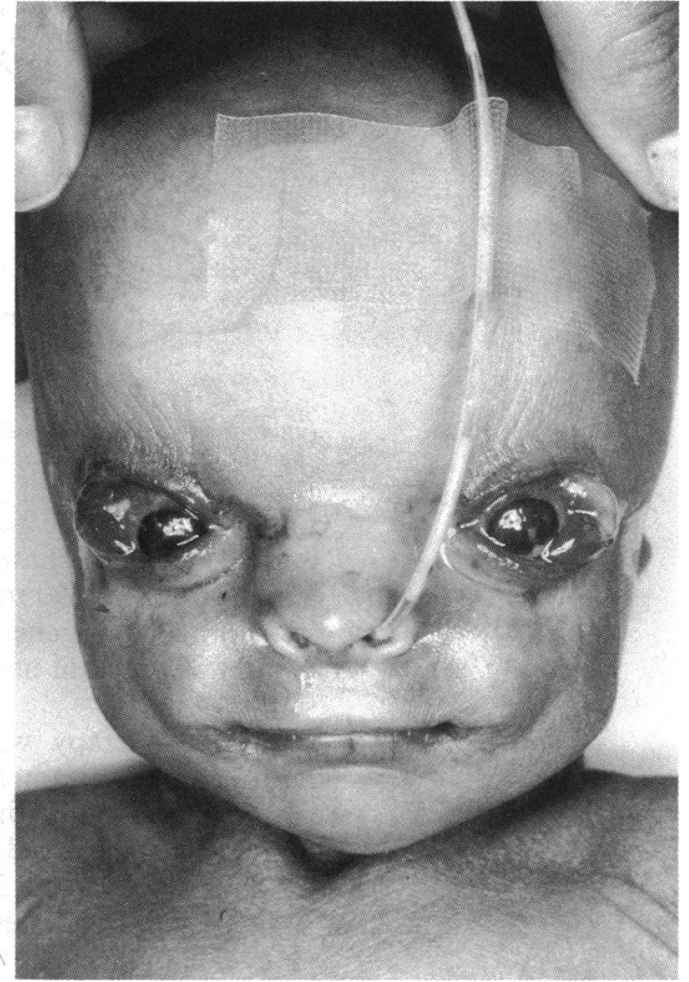

Figure 1 Facial appearance at birth. Ablepharon, the absence of all eyelids, with conjunctival chemosis and corneal ulceration.

On the first postnatal day corneal opacities and gross conjunctival chemosis were noted. By the fourth day bilateral corneal vascularisation and central ulcers had developed. Following intensive topical antibiotics and lubricants, bilateral 'tarsorrhaphies' were attempted but had broken down within two days. On the tenth day corneal cover was achieved by supplementing the upper eyelids with bilobed temporal scalp rotation flaps (Fig 3). By age 7 weeks the corneal ulcers had healed, leaving vascularised central opacities. The lids were functioning well. No



Figure 3 Improved corneal cover and cosmetic appearance following bilateral bilobed temporal scalp rotation flaps. 


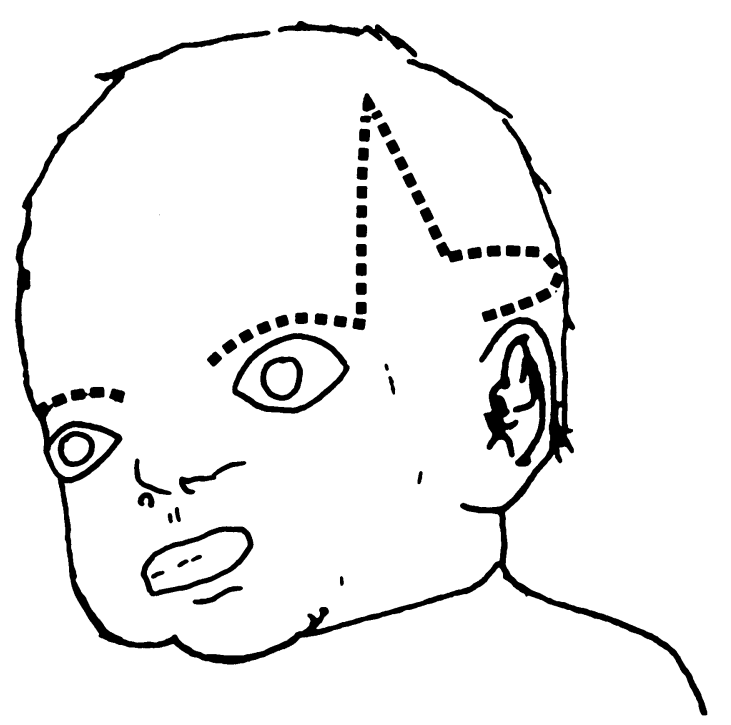

Figure 4 Initial incisions. Bipedicle flaps slide down to form upper lids while rotation flaps fill the resultant defects.

fundal details could be seen. The flash visually evoked response showed a small P2 and large amplitude $\mathrm{P} 3$ at $250 \mathrm{~ms}$. The electroretinogram was normal. His general development at age 15 months was within normal limits for a partially sighted child.

Topical therapy was gradually reduced to liquid paraffin ointment once daily, and by the age of 20 months the corneal opacities had diminished and forced eye closure was complete on both sides. Aged 27 months he underwent right penetrating keratoplasty and bilateral supplementation of the lateral lid regions by means of C-shaped free grafts from the supraclavicular fossae. This improved lid function, cosmetic appearance, and vision. Left penetrating keratoplasty is also planned.

\section{Discussion}

This case and the three cases of AMS reported previously by McCarthy and West ${ }^{1}$ and by Hornblass and Reifler ${ }^{2}$ share features which characterise a distinct condition. All cases show bilateral absence of eyelids, eyebrows, and eyelashes, an apparent failure of lateral lip fusion giving rise to the large fish-like mouth, abnormal ears and nose, ventral hernia, absence of lanugo, ambiguous genitalia, and cryptorchidism.

In contrast, a female case described by Barber et $a l^{3}$ had a remarkably similar facial appearance to the reported cases of AMS but there were other notable differences. ${ }^{3}$ Cesarino $e t a l^{4}$ chose to describe their case as lid agenesis-macrostomiapsychomotor retardation-forehead hypertrichosis because a number of features differed from those in AMS.

It had been suggested that AMS is an autosomal recessive condition, ${ }^{5}$ as ablepharon may occur in association with cryptophthalmos, ${ }^{6-8}$ which shares many similar systemic features with AMS. ${ }^{6-11}$ However, in AMS the periorbital tissues are not fused with the ocular surface, all cases appear to be sporadic, and all chromosomal studies have shown a normal male karyotype.

The ophthalmic management of these neonates begins at birth, with frequent instillation of ocular lubricants and antibiotics. Moisture

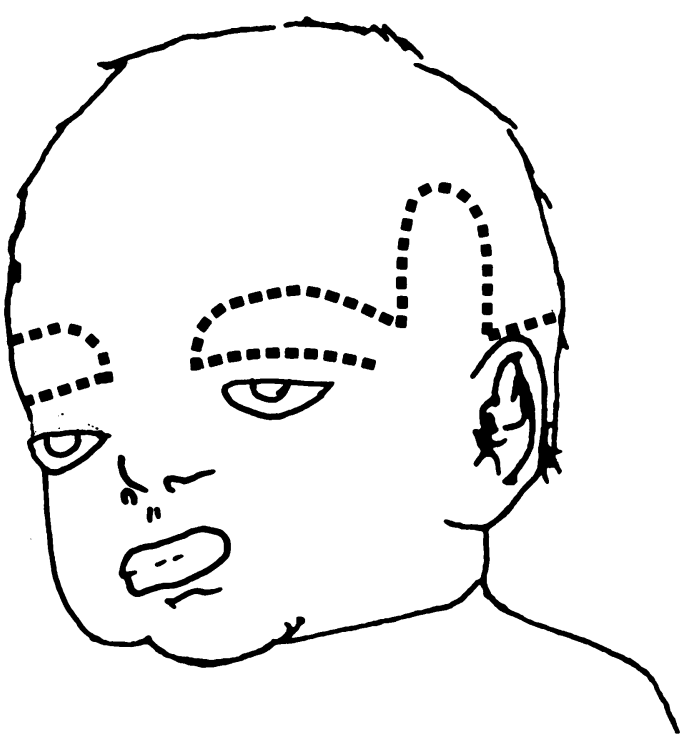

Figure 5 Creation of upper lids following transposition of bilobed rotation flaps.

chambers with plastic wrappings ${ }^{2}$ or even inferior rectus section with upward rotation of the globe $^{12}$ may help as temporary measures.

Most techniques described for four-lid construction in the adult involve stages in which total visual occlusion occurs for some weeks, ${ }^{12-15}$ which in the neonate could induce amblyopia. In our case, once tarsorrhapies had failed, the upper eyelids were lengthened by making horizontal relieving incisions down to the levators and sliding them down as bipedicle flaps. The defects were filled by means of bilobed transposition flaps from the temporal scalp on either side (Figs 4,5 ). The flaps are formed at right angles to each other and then transposed round into the defect. The resultant defect in the first axis is then closed. ${ }^{16}$ There was sufficient conjunctiva present to obviate the need for mucosal grafts. This technique was favoured because it utilised the excessive and hairless temporal scalp skin ${ }^{17}$ and the preseptal orbicularis muscle was retained at the lid margin.

Postulated mechanisms for AMS are a primary developmental failure, a destruction/absorption process, or some mechanical interference. These would not, however, explain the other associated abnormalities. Neural crest-derived cells contribute to the connective tissue of the eyelids. ${ }^{18}$ An ectodermal-mesenchymal induction failure could result in ablepharon and the other manifestations of AMS. The thin dry skin lacking in subcutaneous tissue may indicate a primary skin disorder. Perhaps a defect in skin elastic tissue and therefore skin tension during development results in the observed abnormalities (Donnai D, personal communication, 1986). Thus the eyelids may have been prevented from fusing and thereby completing normal development. There are no reports on skin histology in AMS, but periorbital skin biopsies from our case showed no specific abnormality, and collagen studies gave normal findings.

We thank especially Mr L A Holbrook, of Alder Hey Hospital, Liverpool, for performing the plastic surgery, Dr Michael Pope, of Northwick Park Hospital, for the collagen studies, and the Departments of Medical Illustration at Leighton Hospital, Crewe; Selly Oak Hospital, Birmingham and the Royal Hospital, Wolverhampton, for the illustration. 
1 McCarthy GT, West CM. Ablepharon macrostomia syndrome. Dev Med Child Neurol 1977 19: 659-72.

2 Hornblass A, Reifler DM. Ablepharon macrostomia syndrome. Am f Ophthalmol 1985; 99: 552-6.

3 Barber N, Say B, Bell RF, Merveille OC. Macrostomia ectropion, atrophic skin, hypertrichosis and growth

4 Cesarino EJ, Pinheiro M, Freire-Maia N, Meira-Silva MC. Lid agenesis-macrostomia-psychomotor retardation-forehead hypertrichosis: a new syndrome? Am $\mathcal{F}$ Med Genet 1988; 31: 299-304

5 Gupta SP, Saxena RC. Cryoptophthalmos. Br $\mathcal{F}$ Ophthalmo 1962; 46: 629-32.

6 François J. Malformative syndrome with cryptophthalmia. Int Ophthalmol Clin 1968; 8: 817.

7 Azevedo ES, Biondi J, Ramalho LM. Cryptophthalmos in two familes from Bahia, Brazil. Braz $\mathcal{F}$ Med Genet 1973; 10: 389 92.

8 Sugar HS. The cryptophthalmos-syndactyly syndrome. $A m \mathcal{f}$ Ophthalmol 1968; 66: 897-9.

9 Zehender W, Manz O. Eine Missgeburt mit hautüber wachsenen Augen oder Kryptophthalmus. Klin Monatsbl Augenheilkd 1872; 10: 225-49.

10 Fraser GR. Our genetic 'load'. A review of some aspects of genetic variation. Ann Hum Genet 1962; 25: 387-415.

11 Ide CH, Wollschlaeger PB. Multiple congenital abnormalities associated with cryptophthalmia. Arch Ophthalmol 1969; 81: $638-44$

12 Tessier $P$. Secondary treatment of the injured and mutilated eyelid. In: Tessier P, Callahan A, Mustardé JC, Salyer KE, eds. Symposium on plastic surgery in the orbital region. Proceedings of the symposium of the Educational Foundation of the American Society of Plastic and

13 Mustardé JC. Reconstruction of both lids. In: Mustardé JC Repair and reconstruction in the orbital region. A practical guide. 2nd ed. London: Churchill Livingstone, 1980: 152-4. 14 Hay D. Reconstruction of both eyelids following traumatic loss. Br f Plast Surg 1971; 24: 361-4

15 Achauer BM, Menick FJ. Salvage of seeing eyes after avulsion of upper and lower lids. Plast Reconstr Surg 1985; 75 $11-5$.

16 Dean RK, Kelleher JC, Sullivan JG, Baibak GJ. Bilobed Flaps. In: Grabb WC, Myers MB, eds. Skin flaps. 1st ed. Boston: Little, Brown, 1975: 289-96.

17 Esser JFS. Gestielte lokale Nasenplastik mit Zweizipfligen Lappen, Deckung des sekunderen Defektes vom ersten Zipfel durch den Zweiten. Dtsch Z Chir 1918; 143: 385.

18 Noden DM. Periocular mesenchyme, neural crest and mesodermal interactions. In: Duane TD, Jaeger EA, eds. Biomedical foundations of Ophthalmology. Philadelphia: Biomedical foundations of Ophthalmolog. 